\title{
REFLECTIONS ON THE PARADIGMATIC STATUS OF SOCIOLOGY
}

\author{
George Ritzer \\ University of Maryland
}

Mid-American Review of Sociology, 1978, Vol. III, No. 2:1-15

The 1970 s is a decade in which sociology is characterized by attempts to define its paradigmatic status. In the first systematic effort to apply Thomas Kuhn's (1970) ideas to sociology, Friedrichs (1970) granted most sociological theories the status of a paradigm, or at least a would-be paradigm. However, he relegated these theories to the status of second-order paradigms while the first order, or most controlling, paradigms were those that related to the image the sociologist has of "himself as a scientific agent." The prophetic sociologists are those who see themselves as social critics seeking to debunk social myths while priestly sociologists are more interested in scientific, value-free sociology (Friedrichs, 1970). Effrat (1972) enumerated a long list of sociological paradigms which are really virtually all of the extant sociological theories. Similar in focus, but far more ambitious in scope, was Mullins' (1973) effort to identify the major theory groups in sociology.

The most recent effort to analyze the paradigmatic status of sociology by Eisenstadt and Curelaru (1976) identifies two major paradigmatic schema in sociology, the most notable of which is the differentiation between discrete, closed ssystem, -. and open-system paradigms. Eisenstadt and Curelaru are more concerned than the other authors discussed here with the historical development of the field. Hence their paradigms are framed within this historical context. In their presentation, the earliest sociological approach was the discrete paradigm in which the focus was on separate concrete entities such as ecological properties, size of groups, or racial and psychological characteristics. Given the image of the world as a set of isolated factors, those who operated within this paradigm had difficulty dealing with such relational issues as emergence, innovation, and 
creativity. This early and primative paradigm left only a small mark on the development of sociology and persists today in only isolated domains. It was replaced, historically, by the closed system model whose supporters saw society as composed of separate, but interrelated, elements. Those who operated within this paradigm tended to see one element as dominant over the others. In Eisenstadt and Curelaru's view (but not mine) Marx was operating within this paradigm with his emphasis on the economic sector. This paradigm was replaced, in turn, by the open system model which focused on the "internal systemic dynamics, interconnections, and continuous feedback processes among the components of the social order" (Eisenstadt and Curelaru, 1976:92). Although the evolution of these paradigms follows "no simple, natural, chronological trend," and there is "considerable temporal and operative overlapping of the several approaches," there is in Eisenstadt and Curelaru's view a long-term trend toward the open system paradigm.

In addition to those outlined above, there is my own effort (Ritzer, 1975, 1975a) to analyze the paradigmatic status of sociology. In this paper I would like to discuss this schema in light of recent developments in the field.

Unlike most of the observers discussed above, I do not consider paradigms and theories to be the same thing. Rather, I see a paradigm as subsuming theories, methods, exemplar and image of the subject matter of sociology. Employing a definition of paradigm that employs these four components, I argued that contemporary sociology is dominated by three paradigms-social facts, social definition, and social behavior. Briefly, the social facts paradigm focuses on macro-structures, is characterized by the work " of Emile Durkheim as its exemplar, uses structural-functional and conflict theory, and tends to employ the interview/questionnaire and historical/comparative methods. Those who work within the social definition paradigm focus on the action and interaction that results from the minding process, accept Max Weber's work on social action as the exemplar, employ various theories including action theory, symbolic interactionism, and phenomenology-ethnomethodology, and are more prone in their research to use the observational method. Finally, those who accept the social behavior paradigm focus on behavior and contingencies of reinforcement, view B.F. Skinner's work as their exemplar, operate from behavioral or exchange theory, and tend to prefer the experimental method. I will discuss these paradigms shortly, but first let me say some things about some potential new sociological paradigms.

In my earlier work I contended that sociobiology and critical sociology were showing signs of achieving paradigmatic status within the discipline. If anything, these perspectives show even more vitality today than they did a few years ago. The strength of sociobiology is reflected in the enormous amount of attention devoted to Edward Wilson's (1975) Sociobiology which has been the subject of review essays in the major sociological journals. While this may simply be another cycle in sociology's longstanding love-hate relationship with the issue of how much social behavior can be explained biologically, it could also be that sociologists will finally get over their historic insecurity about biology. This could be the beginning of an era in which a number of sociologists make sociobiology the focus of their work. Already people like Pierre van den Berghe (1975) and Allan Mazur (1972) are identified with this approach. Similarly, critical sociology, which is strong in Europe, is of growing significance in the United States. It seems to be the true inheritor of the neo-Marxism which has been latent in sociology until recent years as well as the now moribund radical sociology of the late 1960s. Reflective of this growth is the increasing familiarity in America with the school in general (Jay, 1973; Bauman, 1976; Connerton, 1976; Stewart, 1978) and in particular with the work of its most important modern exponent, Jurgen Habermas (1968).

Although I did not mention it in my earlier work, it seems clear now that structuralism has the potential of emerging as a new sociological paradigm. At the moment it remains largely on the periphery of sociology with the most notable inputs stemming from linguistics and anthropology, particularly in the work of Levi-Strauss (1969). Structuralism now has its own practitioners (Cicourel, 1974) and defenders (Carpenter, 1976) in sociology and we can anticipate greater interest in the future. However, it is also easy to forecast heightened political attacks. In fact, we have 
already seen Goddard (1976) unleash an attack on this potential paradigm. In Goddard's view, if sociology should accept the structural approach it would "comprise absolutely what is perhaps its own fundamental premise... that ideas and symbols are formed in the material context of given social milieux ... the idea of a sociological materialism which inaugurated sociology as a special discipline would have to be completely abandoned" (Goddard, 1976:132). If structuralism was not a serious contender for paradigmatic status, it would not have been singled out for such a vigorous attack.

In addition to these relatively strong contenders for paradigmatic status, there are a number of other perspectives that are finding at least limited support in sociology. For example, Catton and Dunlap (1978) have recently made a case for what they call "the new environmental paradigm" which focuses on the limits imposed on human action by environmental constraints. As is normal with supporters of new paradigms, we find attacks being made on extant paradigms. Catton and Dunlap (1978:44) are quite explicit in their assault on the social facts paradigm: "It began to appear that, in order to make sense of the world, it was necessary to rethink the traditional Durkheimian norm of sociological purity-i.e., that social facts can be explained only by linking them to other social facts."

These attacks on structuralism and social factism bring us back to the general theme in my earlier work-the pervasiveness of political conflict in sociology. Although some competition and conflict between paradigms is certainly useful, it is clear that these conflicts have frequently had negative consequences for the discipline as a whole. All too often sociologists have exaggerated the capabilities of their approach while viciously attacking the utility of the others. This political conflict has made it difficult to see the intellectual affinity between the various paradigms. Lest we think that this kind of political attack is restricted to supporters of potential paradigms, we need only recall Lewis Coser's (1975) presidential address to the American Sociological Association.

Coser's attack on ethnomethodology is an extreme example of interparadigmatic conflict. In his address, and in much of his work, Coser is an exponent of the social facts paradigm. As such, he can be seen as engaging in a politically motivated attack on a theoretical component of the social definition paradigm. True to the general character of such attacks, Coser sees few redeeming qualities in ethnomethodology and subjects it to a brutal attack. Typical of critics of competing paradigms, Coser engages in a great deal of name-calling in labelling ethnomethodology "trivial," "a massive cop-out," "an orgy of subjectivism," and a "self-indulgent enterprise." The motivation behind this viciousness lies in the fact that social definitionism has long been a competitor with Coser's social factism for preeminence within sociology. This is just the latest of a long history of attacks by proponents of each of these paradigms on the other. Interestingly, the ethnomethodologists, in their reply to Coser, showed far more sensitivity to the dangers of political conflict in sociology, when they called for an integrated study of social facts and social definitions (Mehan and Wood, 1976).

Given these general comments, let me turn to a discussion of the two most important components of sociological paradigms-theories and methods.

\section{Theories}

The theories associated with the social facts paradigm, structural-functionalism and conflict theory, seem to be of declining significance in the discipline. It is difficult to find many young sociologists who are involved in structural-functionalism since they were socialized in the 1960s when it was under such severe attack. Most of the current work in structural-functionalism is still being produced by the senior sociologists who popularized the theory in the 1930s and 1940s. Despite continued writing and the publication of volumes of essays in his honor, Talcott Parsons is fast becoming an historic figure. On the other hand, Robert Merton seems to be on the ascendancy with the appearance of books of his essays as well as a book of essays in his honor. Peter Blau tried to revive structural-functionalism by making the study of social structure the theme of the 1974 ASA meetings and inviting most of the major, and older, structural-functionalists to 
contribute essays. Despite this activity, the fact remains that the dominant figures in this theoretical orientation are aging and there seem to be few young thinkers of their stature to take their place. It appears unlikely to me that the exciting theoretical breakthroughs in sociology in the near future will be coming from structural-functionalists.

There seems to be even less life in conflict theory. The central modern thinker in this tradition, Ralf Dahrendorf (1959), is under increasing attack (e.g., Turner, 1973) and there are few working in this tradition. One of the basic criticisms of Dahrendorf is that his work is simply structural-functionalism turned on its head. In that sense it betrayed its Marxian heritage. I believe that Marxian theory will continue its revival in sociology, but that it will not be within conflict theory. Some (Bottomore, 1975) will return to the original Marxian structural theory unadulterated by the Marxists (Bender, 1975). As such they will continue to work within the social facts paradigm. Another strand will be the critical theorists who will continue to integrate Marxian structural analysis with some sort of social definitionism, such as Freudian theory which is currently in vogue among them. In his recent work, Appelbaum (1978a, 1978b) has also evidenced an interest in integrating Marxian structural analysis with Marx's more subjective concerns: "What distinguishes Marxism from positivist social science is its ability to move simultaneously on two levels: it formulates the laws of the 'natural history' of capitalist economic organization, and at the same time demonstrates the ideological (i.e., historically situated) character of those laws so that they might be repealed by self-conscious workers organized collectively in their own interests" (Appelbaum, 1978a:76, italics mine).

Another theoretical development within the social facts paradigm will be the growing realization that structural-functionalism and conflict theory are not really as antithetical as many have believed. A good example of this trend is a recent essay by Lipset (1975) in which he points to the similarities between Parsonian and Marxian theories of social change.
While discussion of the illusory schism between structural-functionalism and conflict theory should diminish, I think we may see greater recognition of a perhaps more important division among social factists which is manifest in Peter Blau's (1975) collection of essays on social structure. It is clear in those essays that some social factists devote their attention to subjective macroscopic structures while others are concerned with more objective social facts. Historically, I believe that Max Weber was primarily concerned with subjective social facts, as for example, in his analysis of the "spirit" of capitalism. More contemporaneously, Talcott Parsons operates from this position since the cultural system stands at the pinnacle of his four-system model controlling the other systems (social, personality, and biological organism). Indeed, Parsons (1966:113) says: "I am a cultural determinist, rather than a social determinist." A more specific example of the study of subjective social facts is Lipset's (1975:173) contention that a group's structure is its "standardized normative patterns, rights, rules of behavior, and the like." Exemplifying the study of objective social structures is Karl Marx's analysis in Capital of the reified economic structure of capitalist society. More contemporaneously, Blau's (1975) focus on parameters of social structure like race, sex and division of labor is on the objective level. While these two foci (objective and subjective social facts) are not antithetical, I do not believe that many sociologists have been aware of this division among social factists. Yet, it should be noted that in his original formulation Durkheim (1964) differentiated between material and non-material social facts.

Although there will be major changes in the theoretical component of the social facts paradigm, I believe that changes of an even greater magnitude will take place in the theories associated with the social definition paradigm. Action theory seems to be moribund and of little more than historical interest. Weber has been dead for more than one-half a century and Parsons has not practiced action theory in forty years. It is hard to think of any modern theorists who would identify themselves as action theorists (Etzioni might be an exception). Symbolic interactionism seems to be following the lead of action theory into the 
sociological history books. Its place of origin, the University of Chicago, is now identified with a very different kind of sociology, Herbert Blumer has retired, and the apparent inheritor of the mantle, Erving Goffman, has increasingly moved away from the classic symbolic interactionist approach in his most recent work. While there is some counter-evidence here (e.g., a new journal devoted to symbolic interactionism), I still believe that the theory has lost much of its dynamism.

The locus of interest and power within the theoretical component of the social definition paradigm is shifting dramatically in the direction of ethnomethodology and phenomenology. Alfred Schutz, who played a key role in the development of both of these theories, is emerging as a central figure in the history of the discipline with an analysis of his work becoming as important as that of Marx, Weber, Durkheim and Mead. His contemporary followers in phenomenology (e.g., Peter Berger, Thomas Luckmann, and George Psathas) are very active and one of their most widely read products, The Social Construction of Reality (Berger and Luckmann, 1967), is close to becoming a modern classic. Also of some significance is the growth in interest in existentialism (Manning, 1973), particularly the relevance of Jean Paul Sartre (Craib, 1976) for sociology.

However, the big growth field among the theories of social definitionism is likely to be ethnomethodology. This growth is likely to take place despite the opposition of major establishment figures in sociology (Coser, 1975). Ethnomethodology is currently moving in a number of directions ranging from the descriptive analyses of Garfinkel and his students to the linguistic analyses of Cicourel and others (Mehan and Wood, 1975; Zimmerman, 1978). Long tied to the West Coast because of its own clannishness and opposition from more traditional sociologists throughout the country, ethnomethodology now seems to be achieving national recognition. Given the importance of the study of everyday reality, it would seem that the continued growth of ethnomethodology is assured. This bright future could be dampened should most ethnomethodologists leave the world of everyday reality and follow Cicourel into the sometimes highly esoteric study of linguistics.
The theories associated with social behaviorism (behavioral sociology, exchange theory) should continue to be attractive to a relatively small, but significant, number of sociologists (Michaels and Green, 1978). The reductionism of these theories is difficult for most sociologists to accept, but its promise of offering a technology to ameliorate social ills will prove irresistible to at least some sociologists (Tarter, 1973). Another development that could signal a larger audience for theories of social behavior would be a greater understanding of the relationship between mental processes and behavior (Staats, 1976).

\section{Methods}

One of the most controversial aspects of my earlier work was the linking of theories and methods within broader paradigms. I argued that social factists are more likely to use interviews, questionnaires, and the historical/comparative method; social definitionists tend to prefer observational methods; and social behaviorists seem to prefer experiments. I also made it clear that these are only tendencies; all methods are used in all paradigms. What varies is the relative frequencies of the use of these methods by the adherents of each of the paradigms. This fact was brought home once again by Mehan and Wood (1975) who in their analysis of ethnomethodology point out that despite its rejection of the logico-experimental method, some ethnomethodologists are doing experimental research.

I should like to use this opportunity to augment what I have said about the relationship between paradigms and methods. Earlier I castigated social factists for not doing more historical/comparative research and I still believe that this is an underutilized method. However, in recent years we have seen a resurgence of this method in important studies by Wallerstein (1974), Paige (1975) and Chirot (1976).

These points, however, are minor in comparison to the issues raised by Snizek's (1976) research which casts doubt on the linkages between paradigm and method. I cannot repeat all of Snizek's findings, but his key points are that the linkages are not as I assert and that the interview/questionnaire method is the 
dominant method in all three paradigms. Although one must laud Snizek's effort to test my assertions, there are a variety of problems in Snizek's research that make his conclusions problematic (Ritzer, 1977). Nevertheless, additional research may well prove that the cheap and efficient interview/questionnaire is dominant within all paradigms. If this proves to be so, I would argue that it stems from the expediency of sociologists of all persuasions and not from an intellectual affinity between this method and all the paradigms. If interviews and questionnaires are predominant, I would then contend that the experimental method is used more often by social behaviorists than social factists or social definitionists; the observational method is used more by social definitionists than adherents of the other paradigms, and the interview/questionnaire is used more by social factists than the supporters of the other paradigms. A true test of all of this awaits a research project that overcomes the problems in the Snizek research.

\section{Toward Theoretical Integration}

The issue of paradigmatic integration is so multi-faceted and complex that it is difficult to even begin dealing with. However, a focus on theoretical integration is both manageable and an excellent place to begin grappling with the issue of paradigmatic integration.

I perceive a growing interest in, and awareness of, the need for theoretical integration among a wide range of sociologists. Among the structural-functionalists we find Robert Merton (1975:30) arguing that analyses of social structures "connects with other sociological paradigms which, the polemics not withstanding, are anything but contradictory in much of what they suppose or assert ... recent work in structural analysis leads me to spheres of agreement and of complementarity rather than to the alleged basic contradictions between various sociological paradigms." More specifically, Merton (1975:31) later says: "Many ideas in structural analysis and symbolic interactionism, for example, are opposed to one another in about the same sense as ham is opposed to eggs: They are perceptively different but mutually enriching." Among the social definitionists, Mehan and
Wood (1975:180) say that ethnomethodology "begins by accepting the reality of an external and constraining world. To this assumption is added an acceptance of the facticity of ceaseless reality work. The problem of a general theory of social order is thus determining the properties that relate structural activities to structural 'facts.' " More recently, Zimmerman (1978) has rejected the idea that ethnomethodology is a form of "radical subjectivism" and a "species of psychologism." Ethnomethodologists are concerned with subjectivity, but as it exists within a "supraindividual system, a form or forms of social organization" (Zimmerman, 1978:9). It is this need to integrate levels that leads Zimmerman to discuss the possibility of "interchange" between ethnomethodology and more "macrosociological" approaches, particularly neo-Marxism.

Among social behaviorists we find people like Staats (1976) returning to the original Meadian project of integrating the minding process with traditional behaviorism. Even the new sociobiologists are able to see the reconcilability of their approach with other sociological orientations. For example, Wilson (in Barash, 1977:xiv) admits: "Human behavior is dominated by culture in the sense that the greater part, perhaps all, of the variation between societies is based on differences in cultural experience. But this is not to say that human beings are infinitely plastic."

Despite a lengthy list of theorists who recognize the need for theoretical integration we continue to see the tendency to emphasize, and often to overemphasize, the importance of a particular set of variables. Thus, for many social factists individuals are seen to be largely determined by macrostructures while for a large proportion of social definitionists it is individuals who determine social structures. Similar claims are made by the supporters of the other paradigms or would-be paradigms. Although a number of issues are involved in these claims, it seems to me that the central issue is the relationship between macro-structures and micro-consciousness. Instead of focusing on one or the other, sociologists should be concerned with the dialectical relationship between the way people, endowed with creative consciousness, create and are created by larger social 
structures. There is clearly a dialectical relationship between these "levels" of social reality as Marx realized long ago when he recognized that people make history, but they do not make it as they wish. Recently, Ball (1978) has made a similar point in behalf of General Systems Theory. Ball seeks to reject the oft-accepted dualism between consciousness and society (structure). Instead, he sees systems theory as providing a dialectical perspective in which the "individual and society are treated equally, not as separate entities, but as mutually constitutive fields, related through various 'feedback' processes"' (Ball, 1978:68).

Solving the riddle of the relationship between structure and consciousness requires a primary input from theorists identified with social factism and social definitionism, but behaviorists, sociobiologists and structuralists can also be useful. Critical theory can be particularly useful here since it seeks to integrate Marxian social structuralism and social psychology.

I believe that the theoretical linkage between structure and consciousness could lay the groundwork for a new sociological paradigm. While I see this as an important development for sociology, I do not believe that such a paradigm would subsume those that are extant. There would still be a need for sociologists who focus on more specific areas and issues. However, what we will have less need for in the future are those who engage in paradigmatic imperialism, and in so doing exaggerate the significance of their own paradigm while downgrading the significance of the others. I do not subscribe to a totally relativistic position; some approaches are less useful than others. Some may be useless. However, we can learn at least.something from each of the approaches that has achieved, or has the possibility of achieving, paradigmatic status.

\section{REFERENCES}

Appelbaum, Richard

1978a "Marxist Method: Structural Constraints and Social Praxis." The American Sociologist 13:73-81.

1978b "Marx's Theory of the Falling Rate of Profit: Towards a Dialectical Analysis of Structural Social Change." American Sociological Review 43:67-80.
Ball, Richard A

1978 "Sociology and General Systems Theory." The American Sociologist 13:65-72.

Barash, David P.

1977 Sociobiology and Behavior. New York: Elsevier.

Bauman, Zygmunt

1976 Towards a Critical Sociology. London and Boston: Routledge and Kegan Paul.

Bender, Frederic

1975 The Betrayal of Marx. New York: Harper.

Bottomore, Thomas

1975 "Structure and History." In Peter Blau, ed., Approaches to the Study of Social Structure. New York: Free Press.

Berger, Peter and Thomas Luchmann

1967 The Social Construction of Reality. Garden City, New York: Anch or Books.

Blau, Peter, (ed.)

1975 Approaches to the Study of Social Structure. New York: Free Press.

Carpenter, G. Russel

1976 "On Structuralism and the Sociological Domain: Comment on Goddard." American Sociologist 11:133-137.

Catton, William R. and Riley E. Dunlap

1978 "Environmental Sociology: A New Paradigm." The American Sociologist 13:41-49.

Chirot, Daniel

1976 Social Change in a Peripheral Society: The Creation of a Balkan Colony. New York: Academic Press.

Cicourel, Aaron

1974 Cognitive Sociology. New York: Free Press.

Connerton, Paul (ed.)

1976 Critical Sociology. New York: Penguin.

Coser, Lewis

1975 "Presidential Address: Two Methods in Search of a Substance." American Sociological Review 40:691-700.

Craib, Ian

1976 Existentialism and Sociology: A Study of Jean-Paul Sartre. Cambridge: Cambridge University Press.

Dahrendorf, Ralf

1959 Class and Class Conflict in Industrial Society. Stanford: Stanford University Press.

Durkheim, Emile

1964 The Rules of Sociological Method. New York: Free Press. Effrat, Andrew

1972 "Power to the Paradigms: An Editorial Introduction." Sociological Inquiry 42:3-33. 
Mid-American Review of Sociology

Eisenstadt, S.N. and M. Curelaru

1976 The Form of Sociology: Paradigms and Crises. New York: John Wiley and Sons.

Freidrichs, Robert

1970 A Sociology of Sociology. New York: Free Press.

Goddard, Davis

1976 "On Structuralism and Sociology." American Sociologist $11: 123-133$

Habermas, Jurgen

1968 Knowledge and Human Interests. Boston: Beacon Press.

Jay, Martin

1973 The Dialectical Imagination. Boston: Little Brown.

Kuhn, Thomas

1970 The Structure of Scientific Revolutions, 2nd Ed. Chicago: University of Chicago Press.

Levi-Strauss, Claude

1969 The Elementary Structure of Kinship. Boston: Beacon Press. Lipset, Seymour M

1975 "Social Structure and Social Change." In Blau, Approaches Manning, Peter to the Study of Social Structure pp. 172-209.

1973 "Existential Sociology." Sociological Quarterly 14:201-225.

Mazur, Allan and Leon S. Robertson

1972 Biology and Social Behavior. New York: Free Press.

Mehan, Hugh and Houston Wood

1975 The Reality of Ethnomethodology. New York: John Wiley.

1976 "De-secting Ethnomethodology." The American Sociologist $11: 13-21$

Merton, Robert

1975 "Structural Analysis in Sociology." In Blau, ed., Approaches to the Study of Social Structure pp. 21-52.

Michaels, James W. and Dan S. Green

1978 "Behavioral Sociology: Emergent Forms and Issues." The American Sociologist 13:23-29.

Mullins, Nicholas

1973 Theories and Theory Groups in Contemporary American Sociology. New York: Harper and Row.

Paige, Jeffrey

1975 Agrarian Revolution: Social Movements and Export Agriculture in the Underdeveloped World. New York: Free Press.

Parsons, Talcott

1966 Societies: Evolutionary and Comparative Perspectives. Englewood Cliffs, N.J.: Prentice-Hall.

\section{Paradigmatic Status}

Ritzer, George

1975 Sociology: A Multiple Paradigm Science. Boston: Allyn and Bacon.

1975a "Sociology: A Multiple Paradigm Science." The American Sociologist 10:156-167.

1977 "On Testing the Paradigmatic Status of Sociology." The American Sociologist 12:23.

Stewart, John J.

1978 "Critical Theory and the Critique of Conservative Methods." The American Sociologist 13:15-22.

Tarter, Donald

1973 "Heeding Skinner's Call: Toward the Development of a Social Technology." The American Sociologist 9:153-158.

Turner, Jonathan

1973 "From Utopia to Where? A Strategy for Reformulating the Dahrendorf Conflict Model." Social Forces 52:236-244.

Van den Berghe, Pierre

1975 Man in Society: A Biosocial View. New York: Elsevier.

Wallerstein, Immanue

1974 The Modern World-System: Capitalist Agriculture and the Origins of the European World-Economy in the Sixteenth Century. New York: Academic Press.

Wilson, Edward O.

1975 Sociobiology: The New Synthesis. Cambridge: Harvard

Zimmerman, Don $\mathrm{H}$. niversity Press.

1968 "Ethnomethodology." The American Sociologist 13:6-15. 